\title{
Radiological Hazards Assessment of Radionuclides in Sediment Samples of Tigris River in Mosul city, Iraq
}

Taha Yaseen Wais and Laith A. Najam

Department of Physics, College of Science, University of Mosul, Mosul, Iraq

\begin{tabular}{l} 
ART ICLE INFO \\
\hline Article history: \\
Received: $16^{\text {th }}$ Apr. 2021 \\
Accepted: $15^{\text {th }}$ Aug. 2021 \\
\hline Keywords: \\
Tigris River, \\
Sediment, \\
Natural Radioactivity, \\
Radionuclides, \\
Radiological Hazards indices.
\end{tabular}

\section{INTRODUCTION}

The phenomenon of radioactivity is one of the eternal phenomena that induces soil, water, air, as well as animal and plant food contamination due to the presence of radionuclides resulting from this phenomenon[1].

Since the inception of the universe there have been primitive radionuclides which are described as naturally occurring[2]. Almost $96 \%$ total radiation dose to humans are from natural sources, while $4 \%$ is from humansmade sources[3,4,5]

Radioactivity is described as a process of spontaneous transformation of the radioactive nuclei of an element into the nuclei of atoms of other more stable elements through the emission of a certain type of radiation from particles known as alpha particles or beta particles (positive or negative ) and accompanied by the emission of electromagnetic radiation known as gamma rays, which then turn into more stable nuclei [6].

Because of the presence of natural radionuclides in different geological formations such as soil, sand, rocks, water, sediments and building materials, humans are exposed to natural radioactivity. The location and height of these formations are the factors on which human exposure to radiation depends[7], and the natural radioactivity comes in the sediments through the uranium-238, thorium-232 and potassium-40 series. [8].

Through direct exposure, ingestion of food and drinking water, humans are constantly exposed to the hazard of accumulation of radionuclides, so the available literature reveals that these radionuclides are important for assessing the dose in humans[9]. Most of the radiation that occurs naturally in the world comes from 
cosmic radiation sources and terrestrial radiation sources, thousands of years ago the radiation dose was higher than it is today, and life is still thriving and present, and the average radiation dose per year all over the world is (2.4) $\mathrm{mSv} / \mathrm{y}[10]$.

The sediments occur as a result of rock weathering and bear the original mineral characteristics that form the rocks, so the sediments reflect the geological history of the transport and dredging process[11]. Radioactivity exists in different geological formations in different concentrations depending on the origin of the geochemical environment and the type of rocks where the radioactive nodes are transported to the soil and sediments when the natural rocks are dissolved and transported by the rain and flows[12].

The aim of the present study is to find out the degree of radioactive hazard of sediments of the Tigris River in the city of Mosul, the center of Nineveh Governorate, northern Iraq, where the risk indicators were calculated based on the values of the concentrations of specific activities of the studied samples

\section{MATERIALS AND METHODS}

\subsection{Location of study}

Mosul is located in the north of Iraq, and it is the center of Nineveh Governorate. It is (465) km away from the capital, Baghdad. The city bisects the Tigris River into two halves, and the city is located between longitude $36^{\circ}$ and latitude $43^{\circ}$. It was necessary to conduct the study because the elements of the environment are affected by the radioactivity and the environmental neglect that the city suffers from due to the destruction that the city was exposed to during the war. The Tigris River in the city is the main source for supplying the population with drinking water and is used for agricultural and irrigation purposes, as shown in Figure(1).

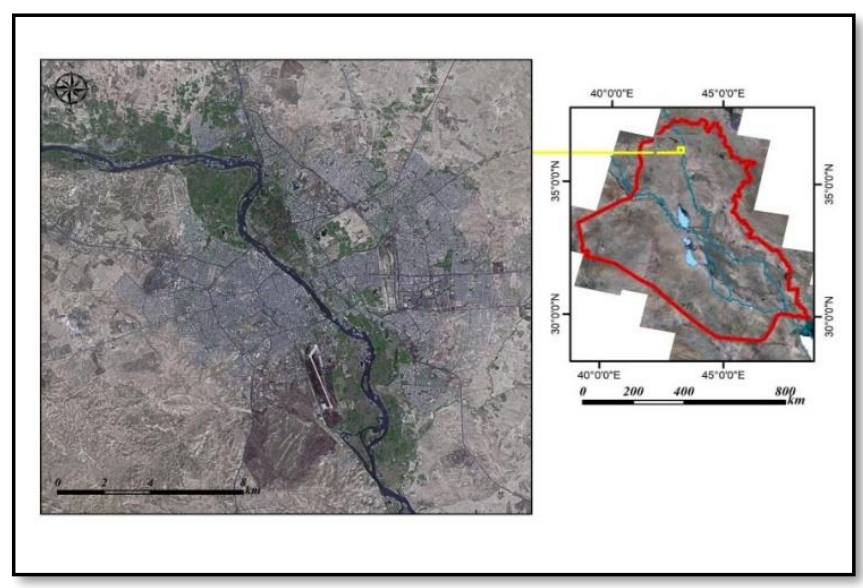

Fig. (1): the location of the city of Mosul in the Nineveh Governorate in northern Iraq

\subsection{Sample Collection and Preparation}

Ten samples were collected from sediments of the Tigris River in the city of Mosul

(see Fig. 2), at a depth of 0.5-1 $\mathrm{m}$ from the river bank. This is to measure natural radionuclides ${ }^{226} \mathrm{Ra}$, ${ }^{232} \mathrm{Th}$, and ${ }^{40} \mathrm{~K}$. The mass of each sample of the collected wet samples ranged between $1-1.5 \mathrm{~kg}$, after which the samples were dried by exposing them to sunlight for a period of 7 days and placed in a thermal oven at a temperature of $105{ }^{\circ} \mathrm{C}$, and by using an electric mill, the samples were ground and sifted. Using a net diameter of $0.75 \mu \mathrm{m}$, samples were weighed $500 \mathrm{gm}$ and placed in a plastic container made of sealed polyethylene and kept for 21days in order to ensure the achievement of the radiative balance between the natural radionuclides and their daughter[13].

Table (1): the symbols, names and coordinates of the samples sites from the Tigris River sediments in the city of Mosul

\begin{tabular}{|c|c|c|c|c|}
\hline $\begin{array}{c}\text { Sample } \\
\text { No. }\end{array}$ & $\begin{array}{c}\text { Sample } \\
\text { ID }\end{array}$ & $\begin{array}{c}\text { Sample } \\
\text { Location }\end{array}$ & Coordinates-X & Coordinates-Y \\
\hline 1 & RS1 & Mushirifa & 325328.613017 & 4029153.71777 \\
\hline 2 & $\mathrm{RS} 2$ & $\begin{array}{l}\text { Mosul Water } \\
\text { Project }\end{array}$ & 326577.978016 & 4029396.87034 \\
\hline 3 & RS3 & Fourth Church & 328290.612034 & 4029598.18643 \\
\hline 4 & RS4 & $\begin{array}{l}\text { Church } \\
\text { Container }\end{array}$ & 329716.956863 & 4029201.34287 \\
\hline 5 & RS5 & $\begin{array}{c}\text { The Victory } \\
\text { Bridge }\end{array}$ & 330086.580519 & 4026838.18564 \\
\hline 6 & RS6 & $\begin{array}{c}\text { Church } \\
\text { Container2 }\end{array}$ & 330896.33943 & 4028627.91908 \\
\hline 7 & RS7 & $\begin{array}{l}\text { The Third } \\
\text { Bridge }\end{array}$ & 330717.348447 & 4025689.23022 \\
\hline 8 & RS8 & $\begin{array}{l}\text { Atomic Medical } \\
\text { Hospital }\end{array}$ & 331002.966727 & 4025427.77726 \\
\hline 9 & RS9 & $\begin{array}{l}\text { Republic } \\
\text { Hospital }\end{array}$ & 331276.017273 & 4025209.7337 \\
\hline 10 & RS10 & $\begin{array}{l}\text { Pashtabiya } \\
\text { Castle }\end{array}$ & 331519.36828 & 4025034.05002 \\
\hline
\end{tabular}

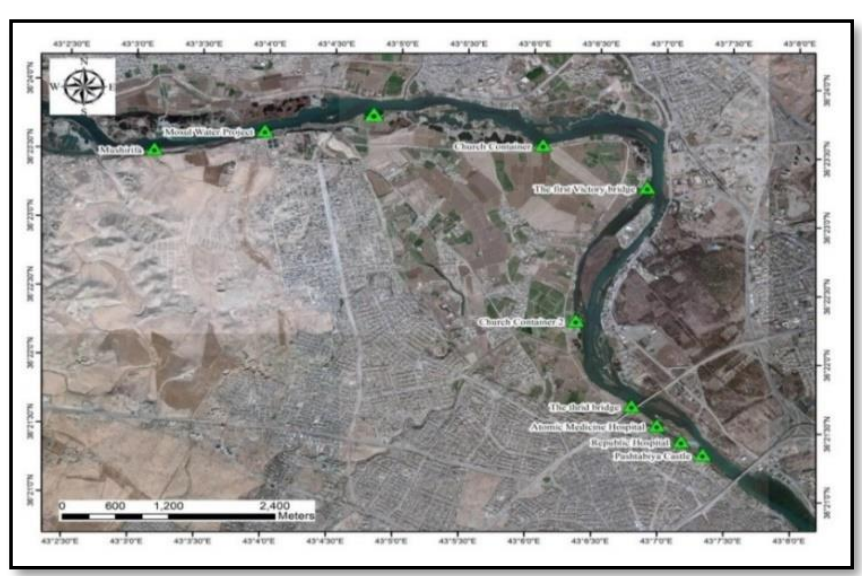

Fig. (2): Sampling Locations 


\subsection{Gamma-Ray Spectrometry}

The gamma spectra were collected from sediment samples of the Tigris River in the city of Mosul by means of gamma ray spectroscopy. A Scintillation detector with specifications (Oak Ridge, TN 37830, United States of America) with a radius of (3.8) $\mathrm{cm}$ and a thickness of (2.5) cm was used, if the detector tube was connected to the voltage supply. The high voltage (the voltage used in this study was 600 volts) and from the detector to the primary amplifier and then to the multichannel analyzer that connects to the calculator via a USB connection cable. Where the calculator displays visual images of the gamma ray spectrum through an installed program, and the detector and the detector holder were covered with lead plates in order to reduce the radiation background recorded by the detector. The power calibration of the detector and the efficiency calibration were performed using standard sources. By using the energy barium source ${ }^{133} \mathrm{Ba}(356) \mathrm{keV}$, the cesium source ${ }^{137} \mathrm{Cs}$ with energy (661.6) $\mathrm{keV}$ and the energy cobalt source ${ }^{60} \mathrm{Co}$ (1332.5) $\mathrm{keV}$ for the purpose of conducting the energy calibration of the detector, As energy calibration is one of the most important factors that should be taken into account before starting the analysis process in order to obtain accurate results, due to the fact that the interpretation of the gamma spectrum depends on radionuclides and energy instead of voltage and channel number [14].After that, the efficiency calibration was performed using a standard source with known energies, if the isotope eurpium-152 $\left({ }^{152} \mathrm{Eu}\right)$ was used, which contains a number of energies ranging from (1408.0-121.8) keV placed in a Marnelli Baker's vessel.

\section{Evaluation of Radiological Hazard Effects}

The natural radionuclide concentrations in the Tigris sediments were used for radium, thorium and potassium in order to calculate the radiation hazard indicators for humans resulting from the continuous exposure to the radiation present in the surrounding environment.

\subsection{Radium Equivalent (Ra $\left.\mathbf{e q}_{\mathrm{eq}}\right)$}

The equivalent activity of radium is defined as a radiation factor using the uniform distribution of natural radionuclides represented by radium-226, thorium-232 and potassium-40, and it is measured in units of $\mathrm{Bq} / \mathrm{kg}$ and Radium equivalent can be calculated though the following equation $[15,16]$ :

$$
R a_{e q}(B q / k g)=A_{R a}+1.43 A_{T h}+0.077 A_{K}
$$

Where $A_{R a}, A_{T h}$ and $A_{K}$ are the specific activity of radium-226, thorium-232 and potassium-40 in units of
$\mathrm{Bq} / \mathrm{kg}$. The maximum universally permitted value of equivalent radium activity $\left(\mathrm{Ra}_{\mathrm{eq}}\right)$ is $370 \mathrm{~Bq} / \mathrm{kg}$.

\subsection{Absorbed Dose Rate in Air $\left(D_{\gamma}\right)$}

The rate of absorbed dose of gamma rays in the air at one meter $(1 \mathrm{~m})$ above the ground level can be calculated using the specific activity of radium-226, thorium-232 and potassium-40, and it can be calculated though the following equation $[16,17]$ :

$D_{\gamma}(n G y / h)=0.462 A_{R a}+0.604 A_{T h}+0.0417 A_{K}$

Where :

$D_{\gamma}:$ Absorbed dose rate in $\mathrm{nGy} / \mathrm{h}$.

$A_{R a}$ and $A_{T h}$ and $A_{K}$ represent the specific activity of radium-226, thorium-232 and potassium-40 in $\mathrm{Bq} / \mathrm{kg}$ unit.

The conversion factors used to calculate the absorbed dose of gamma rays in air correspond to $(0.462 \mathrm{nGy} / \mathrm{h})$ for radium-238, $(0.604 \mathrm{nGy} / \mathrm{h})$ for thorium-232 and $(0.0417 \mathrm{nGy} / \mathrm{h})$ for potassium-40

\subsection{Annual Effective Dose Equivalent (AEDE)}

The annual equivalent dose means that the radiological factor used to judge the extent of the health effects resulting from the absorbed dose, and it is measured in units $(\mathrm{mSv} / \mathrm{y})$. Effective as well as by using the external occupancy factor $(0.2)$ and the internal occupancy factor (0.8). The annual effective dose equivalent (outside the home) can be calculated through the following equation $[15,16]$ :

$$
A E D E_{\text {out }}(\mathrm{mSv} / \mathrm{y})=D \times 10^{-6} \times 8760 \times 0.7 \times 0.2
$$

The annual effective dose equivalent (indoor) can also be calculated using the following equation:

$$
A E D E_{\text {in }}(m S v / y)=D \times 10^{-6} \times 8760 \times 0.7 \times 0.8
$$

\subsection{Hazard Index (H)}

Hazard guide is a radiological parameter used to identify and evaluate external and internal radiation hazards. The external hazard index $\left(\mathrm{H}_{\mathrm{ex}}\right)$ and the internal hazard index $\left(\mathrm{H}_{\text {in }}\right)$ are calculated through the following equations:

$$
\begin{aligned}
& H_{e x}=\frac{A_{R a}}{370}+\frac{A_{T h}}{259}+\frac{A_{K}}{4810} \\
& H_{i n}=\frac{A_{R a}}{185}+\frac{A_{T h}}{259}+\frac{A_{K}}{4810}
\end{aligned}
$$


$\mathrm{A}_{\mathrm{Ra}}, \mathrm{A}_{\mathrm{Th}}$, and $\mathrm{A}_{\mathrm{K}}$ : Radium-226, thorium-232 and potassium-40 are the specific activity in units $(\mathrm{Bq} / \mathrm{kg})$.

The hazard index values must be smaller or equal to one, to be within the internationally accepted limits approved by international scientific institutions $[15,16]$

\subsection{Gamma Radiation Level Index ( $\left.I_{\gamma}\right)$}

The hazard index for gamma rays $I_{\gamma}$ means that it is a radiological factor by which the hazard levels of gamma rays associated with natural radionuclides are estimated in the studied samples. The hazard index for gamma rays can be calculated through the following equation:

$$
I_{\gamma}=\frac{A_{U}}{150}+\frac{A_{T h}}{100}+\frac{A_{K}}{1500}
$$

The hazard index values for gamma rays should be less than or equal to one, which is the internationally accepted limit [18].

\section{RESULT AND DISCUSSION}

The natural radionuclides present in sediments such as ${ }^{226} \mathrm{Ra},{ }^{232} \mathrm{Th}$ and ${ }^{40} \mathrm{~K}$ contribute to the amount of radiation in a large way, as most of the population is exposed to that radiation in those areas, and calculating the value of that radiation is of great importance in knowing the radiation that humans are exposed to by comparing these values with the world recommended values.

The activity concentrations were calculated for ${ }^{226} \mathrm{Ra}$, ${ }^{232} \mathrm{Th}$ and ${ }^{40} \mathrm{~K}$, and it was found that they range between (6.30 $\pm 0.319-13.73 \pm 0.411) \mathrm{Bq} \cdot \mathrm{kg}^{-1}$ with an average value of $(9.86 \pm 0.385) \mathrm{Bq} / \mathrm{kg}$ and between $(13.39 \pm 0.626$ $29.84 \pm 0.923) \mathrm{Bq} / \mathrm{kg}$ and with an average value of (23.05 \pm 0.838$) \quad \mathrm{Bq} / \mathrm{kg}$ and between (166.83 \pm 6.456 $275.96 \pm 7.601) \mathrm{Bq} / \mathrm{kg}$ and an average of $(232.91 \pm 6.456)$ $\mathrm{Bq} / \mathrm{kg}$, respectively. Then the hazard indicators were calculated according to these values, and Table (2) shows the value of the hazard indicators calculated for these regions.

The variation in the values of the radioactive concentrations is a result of the chemical, physical and geological differences of the Earth. The results showed that the average radionuclide concentrations ${ }^{226} \mathrm{Ra},{ }^{232} \mathrm{Th}$ and ${ }^{40} \mathrm{~K}$ were less than the average of globally permissible values as it appears in Table (2). The radium equivalent value $\left(\mathrm{Ra}_{\mathrm{eq}}\right)$ of the studied sediment samples ranged between (38.52) $\mathrm{Bq} / \mathrm{kg}$ in the sample (RS8) and between (71.96) $\mathrm{Bq} / \mathrm{kg}$ in the sample (RS4) in the sample and with an average (60.76) $\mathrm{Bq} / \mathrm{kg}$, which is less than the internationally recommended value, which should not exceed (370) Bq/kg as shown in Figure (3). As for the percentage of absorbed dose, it ranged between (17.81) $\mathrm{nGy} / \mathrm{h}$ in the sample (RS4) and (33.07) $\mathrm{nGy} / \mathrm{h}$ in the sample (RS8) and with an average (28.16) $\mathrm{nGy} / \mathrm{h}$, as shown in Figure (4). and it is also less than internationally recommended value of (55) $\mathrm{nG} / \mathrm{h}$. Also, the lowest value of the average effective dose annual equivalent to external exposure $\left(\mathrm{AEDE}_{\text {out }}\right)$ is in sediment samples (21.84) $\mu \mathrm{Sv} / \mathrm{y}$ for the sample (RS4), the highest value for (40.55) $\mu \mathrm{Sv} / \mathrm{y}$ for the sample (RS8), and the general rate (34.53) $\mu \mathrm{Sv} / \mathrm{y}$ as shown in the Figure(5). which is less than the globally permissible value, which should not exceed (1000) $\mu \mathrm{Sv} / \mathrm{y}$, The lowest value of the annual effective dose rate for internal exposure (AEDE $\left.\mathrm{An}_{\text {in }}\right)$ in sediment samples (87.36) $\mu \mathrm{Sv} \cdot \mathrm{y}^{-1}$ for the sample (RS4), the highest value (162.22) $\mu \mathrm{Sv} / \mathrm{y}$ for the sample (RS8), and the general rate (138.16) $\mu \mathrm{Sv} / \mathrm{y}$ as shown in the Figure(6), which is less than the globally permissible value, which should not exceed (1000) $\mu \mathrm{Sv} / \mathrm{y}$.The value of the internal hazard index was less than the globally permissible values, and its value ranged between (0.120) in the sample (RS4) and between (0.229) in the sample (RS8) and with an average of (0.190) as shown in the Figure (7). For the value of the external hazard index for all the studied sediment samples, it was less than the permissible average globally, as its value ranged between (0.102) in the sample (RS4) and between (0.194) in the sample (RS8) and with an average of (0.163) as shown in the Figure (8). The gamma index, its value ranged between (0.284) in the sample (RS4) and (0.529) in the sample (RS8) and with an average (0.450), and the figure (9) shows those values, which is less than the global permissible value, which should not exceed (1000) $\mu \mathrm{Sv} / \mathrm{y}$. 
Table (2): The hazard indices values calculated in this study

\begin{tabular}{cccccccccc}
\hline Sample No. & Sample ID & $\mathrm{Ra}_{\mathrm{eq}} \mathrm{Bq} / \mathrm{kg}$ & $\mathrm{D}_{\mathrm{\gamma}} \mathrm{nGy} / \mathrm{h}$ & $\mathrm{AEDE}_{\text {out }} \mu \mathrm{Sv} / \mathrm{y}$ & $\mathrm{AEDE}_{\text {in }} \mu \mathrm{Sv} / \mathrm{y}$ & $\mathrm{H}_{\mathrm{ex}}$ & $\mathrm{H}_{\mathrm{in}}$ & $\mathrm{I}_{\mathrm{\gamma}}$ \\
\hline 1 & $\mathrm{RS} 1$ & 61.01 & 28.42 & 34.85 & 139.41 & 0.164 & 0.192 & 0.454 \\
2 & $\mathrm{RS} 2$ & 56.36 & 26.58 & 32.59 & 130.39 & 0.152 & 0.169 & 0.427 \\
3 & $\mathrm{RS} 3$ & 68.80 & 31.37 & 38.47 & 153.88 & 0.185 & 0.213 & 0.504 \\
4 & $\mathrm{RS} 4$ & 71.96 & 33.07 & 40.55 & 162.22 & 0.194 & 0.229 & 0.529 \\
5 & $\mathrm{RS} 5$ & 70.89 & 32.56 & 39.93 & 159.72 & 0.191 & 0.219 & 0.523 \\
6 & $\mathrm{RS} 6$ & 61.73 & 28.62 & 35.09 & 140.39 & 0.166 & 0.189 & 0.459 \\
7 & $\mathrm{RS7}$ & 51.78 & 24.44 & 29.97 & 119.89 & 0.139 & 0.165 & 0.389 \\
8 & $\mathrm{RS} 8$ & 38.52 & 17.81 & 21.84 & 87.36 & 0.102 & 0.120 & 0.284 \\
9 & $\mathrm{RS} 9$ & 58.97 & 27.19 & 33.34 & 133.38 & 0.159 & 0.187 & 0.435 \\
10 & $\mathrm{RS} 10$ & 67.61 & 31.59 & 38.74 & 154.96 & 0.182 & 0.219 & 0.503 \\
\hline Average & & 60.76 & 28.16 & 34.53 & 138.16 & 0.163 & 0.190 & 0.450 \\
\hline Min. & & 38.52 & 17.81 & 21.84 & 87.36 & 0.102 & 0.120 & 0.284 \\
\hline Max. & & 71.96 & 33.07 & 40.55 & 162.22 & 0.194 & 0.229 & 0.529 \\
\hline Average World & & 370 & 55 & 1000 & 1000 & 1 & 1 & 1 \\
\hline
\end{tabular}

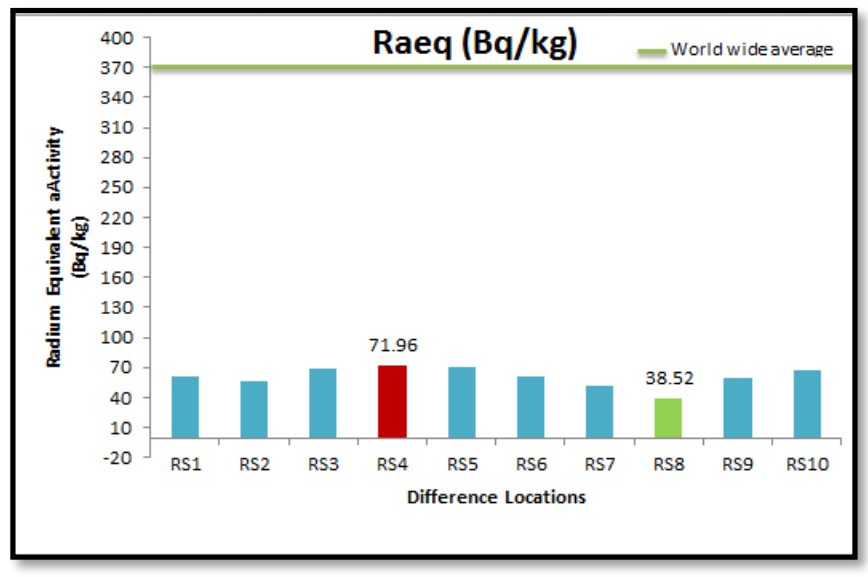

Fig. (3): Equivalent levels of radium activity ( $R a_{\text {eq }}$ ) in the Tigris River sediments in the city of Mosul

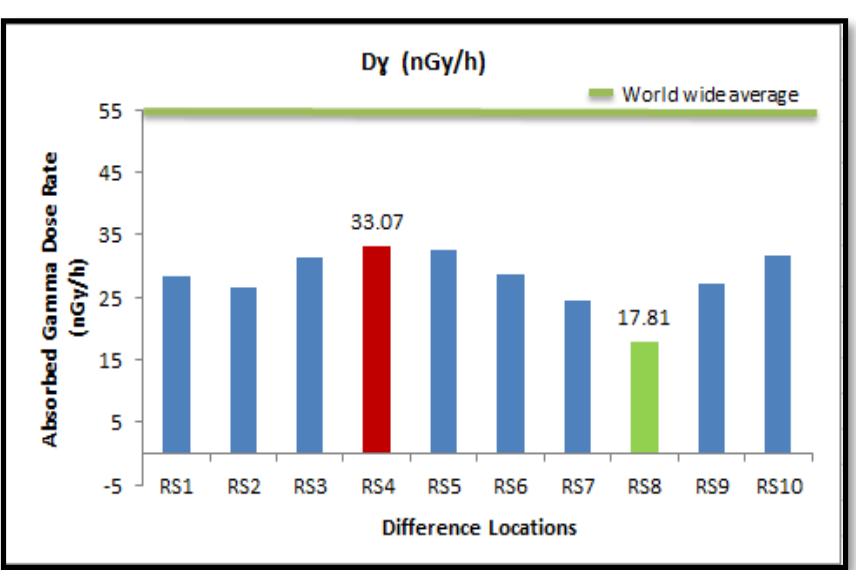

Fig. (4): The levels of absorbed dose in the air (Dy) in sediment samples of the Tigris River in the city of Mosul

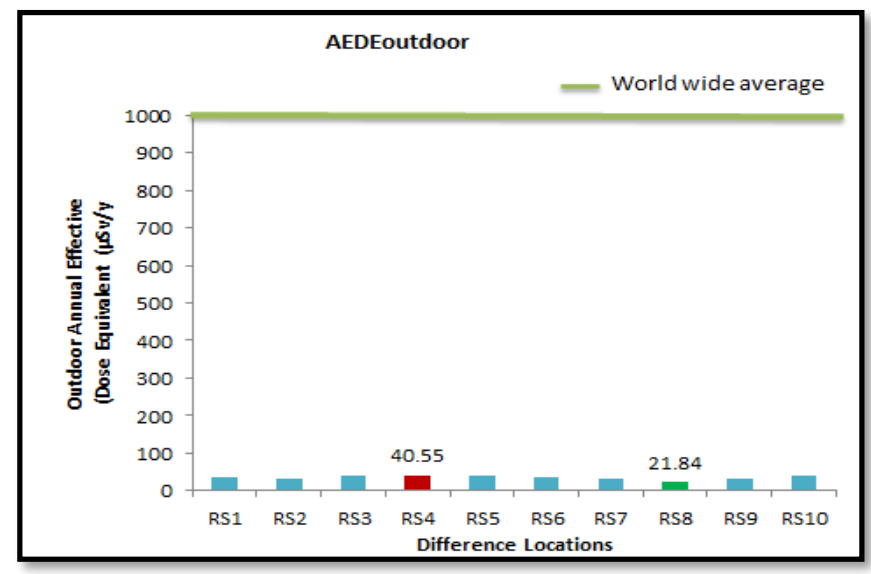

Fig.(5): Annual effective dose rate levels for external exposure (AEDE outdoor $_{\text {) in sediment samples }}$

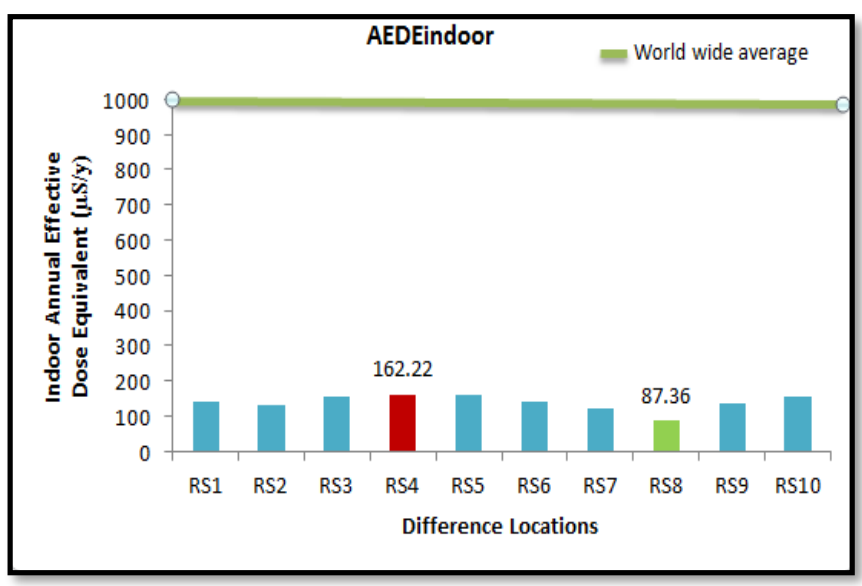

Fig. (6): Annual effective dose rate of internal exposure (AEDE indoor $_{\text {) levels in sediment samples }}$

Arab J. Nucl. Sci. Appl., Vol. 55, 1, (2022) 


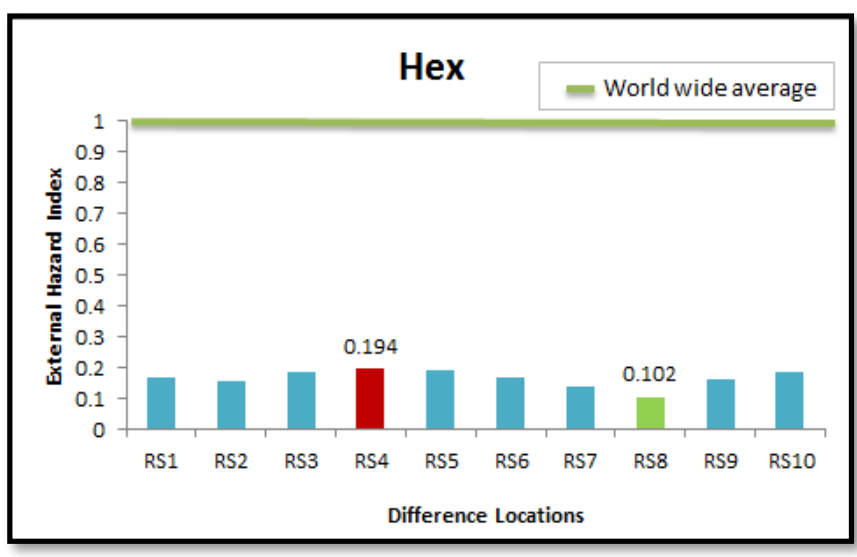

Fig. (7): Levels of external hazard index in sediment samples

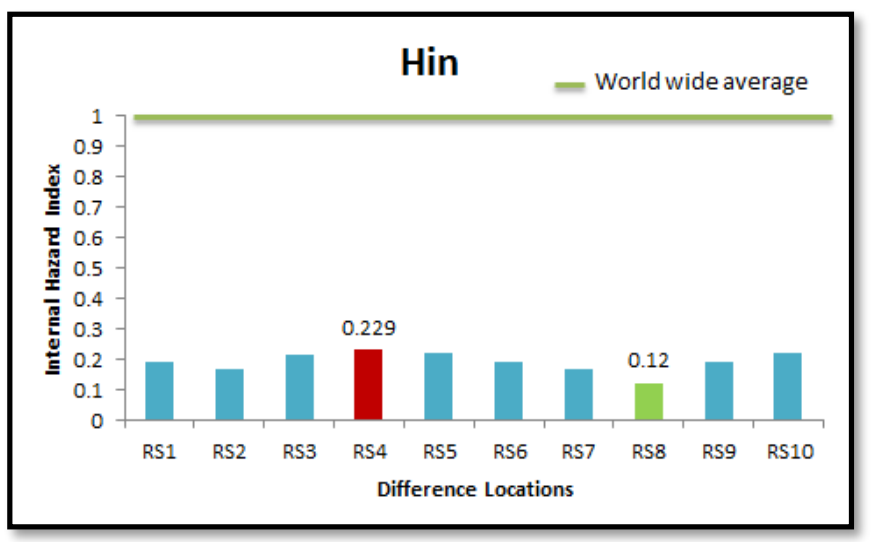

Fig. (8): Internal hazard index levels in sediment samples

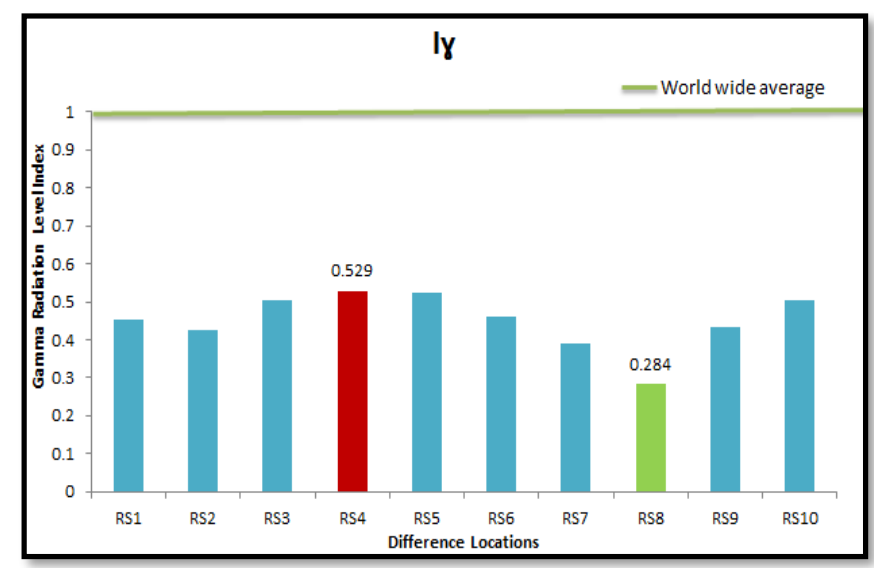

Fig. (9): gamma-ray hazard index levels in sediment samples

The activity concentrations and the radiological hazards of the natural radionuclides of interest in sediment samples from the present study compared to values reported for different parts of the Iraq and world in Table (3).

Table (3): Activity concentration of natural radionuclides and radiological hazards in sediment samples from the studied areas compared with those from other parts of the Iraq and the world

\begin{tabular}{|c|c|c|c|c|c|c|c|c|c|c|c|}
\hline \multirow[b]{2}{*}{ Country } & \multirow[b]{2}{*}{${ }^{226} \mathrm{Ra} \mathrm{Bq} / \mathrm{kg}$} & \multirow[b]{2}{*}{${ }^{232} \mathrm{Th} \mathrm{Bq} / \mathrm{kg}$} & \multirow[b]{2}{*}{${ }^{40} \mathrm{~K} \mathrm{~Bq} / \mathrm{kg}$} & \multirow[b]{2}{*}{$\mathrm{R}_{\mathrm{eq}} \mathrm{Bq} \cdot \mathrm{kg}^{-1}$} & \multirow[b]{2}{*}{$\mathrm{D}_{\mathrm{\gamma}} \mathrm{nGy} / \mathrm{h}$} & \multicolumn{2}{|c|}{$\begin{array}{l}\mathrm{AEDE} \\
\mathrm{mSv} / \mathrm{y}\end{array}$} & \multicolumn{2}{|c|}{ Hazard indices } & \multirow{2}{*}{ Iy } & \multirow[b]{2}{*}{ Reference } \\
\hline & & & & & & $\mathrm{AEDE}_{\text {out }}$ & $\mathrm{AEDE}_{\text {in }}$ & $\mathrm{H}_{\mathrm{ex}}$ & $\mathrm{H}_{\text {in }}$ & & \\
\hline Iraq & 15.48 & 8.36 & 418.47 & 56.38 & 27.76 & 0.04 & 0.16 & 0.16 & 0.20 & 0.41 & [20] \\
\hline Iran & 22.86 & 27.26 & 409.04 & 93.34 & 45.78 & 0.06 & & 0.25 & 0.32 & 0.70 & [21] \\
\hline Egypt & 5.02 & 13.15 & 200.26 & 38.25 & 18.38 & 0.023 & 0.092 & 0.106 & 0.120 & 0.30 & [22] \\
\hline Nigeria & $1-26$ & $2.2-70.3$ & $43.1-468$ & 67.5 & 31.3 & 0.04 & & 0.2 & & & [23] \\
\hline Iraq & 9.86 & 23.05 & 232.91 & 71.96 & 33.07 & 0.034 & 0.138 & 0.194 & 0.229 & 0.529 & Present work \\
\hline
\end{tabular}




\section{CONCLUSION}

The hazard indicators were calculated for ten samples from sediments of the Tigris River in the city of Mosul, northern Iraq, and the results showed that the average value of the radium equivalent was less than the maximum globally permissible value of (370) Bq.kg${ }^{1}[19]$, as well as the average value of the rate of the absorbed dose in the air was less than the average value allowed In addition, The results of calculating the annual effective dose for external and internal exposure showed that it was within the global permissible rates, the results of the calculation of the internal and external hazard indicators showed that they were within the permissible rates globally, as they did not exceed one, as well as the average value of the gamma radiation level index drawn for those areas did not exceed one and is also less than the rates permissible globally. Likewise, the gamma radiation level index calculated for those regions did not exceed one, which is less than the global permissible rates. As a result, it can be concluded that all the studied areas are safe for residents, tourists and their workers, and there is no hazard of exposure to radiation in these areas, as all the results of the hazard indicators for these areas were within the globally permissible values.

\section{ACKNOWLEDGEMENT}

The authors would like to extend their thanks and gratitude to the Physics Department at the Faculty of Science at the University of Mosul and to everyone who contributed to the completion of this research.

\section{REFERENCES}

[1] Miles, J. C., and Algar, R.A., Measurements of Radon Decay Product Concentrations Under Power Lines, Radiation Prot, Dosimetry, 74(2),193- .194,1997

[2] Altuunsoy EE, Tekin HO, Mesbahi A, Akkurt I (2020)MCNPX simulation for radiation dose absorption of anatomical regions and some organs. Acta Phy Pol A 137:561-565.

[3] Ajayi OS (2009) Measurement of activity concentrations of ${ }^{40} \mathrm{~K},{ }^{226} \mathrm{Ra}$ and ${ }^{232} \mathrm{Th}$ for assessment of radiation hazards from soils of the southwestern region of Nigeria. Radiat Environ Biophys48:323332.

https://doi.org/10.1007/s00411-009-0225-0

[4] Chougaonkar MP, Eappen KP, Ramachandran TV et al (2004) Profiles of doses to the population living in the high background radiation areas in Kerala, India. J Environ Radioact 71:275-297. https://doi.org/10.1016/S0265-931X(03)00174-7
[5] Hanfi MY, Yarmoshenko IV, Seleznev AA, Zhukovsky MV (2019) The gross beta activity of surface sediment in different urban land- scape areas. J Radioanal Nucl Chem. https://doi.org/10.1007/s10967-019-06657-9

[6] Warren C.E., "Biology and Water Pollution Control", W.B. Sanders Company, London, p.434, (1971).

[7] Senthil Kumar, C.K. ,Chandrasekaran, A. ,Harikrishnan, N. and Ravisankar, R. ,2020. Measurement of ${ }^{226} \mathrm{Ra}$, ${ }^{232} \mathrm{Th}$ and ${ }^{40} \mathrm{~K}$ and the associated radiological hazards in Ponnai river sand, Tamilnadu, India using Gamma ray spectrometry, International Journal of Environmental Analytical Chemistry, https://doi.org/10.1080/03067319.2020.1796996

[8] Veiga, R., Sanches, N., Anjos, R.M., Macario, K., Bastos, J., Iguatemy, M., Aguiar, J.G., Santos, A.M.A., Mosquera, B., Carvalho, C., BaptistaFilho, M., Umisedo, N.K., 2006. Measurements of natural radioactivity in Brazilian beach sands. Radiation Measurements 41, 189-196.

[9] Fares, S. (2017). Measurements of natural radioactivity level in black sand and sediment samples of the Temsah Lake beach in Suez Canal region in Egypt. . Journal of Radiation Research and Applied Sciences, . 10(13), PP. 194-203.

[10] (Radiophobia, 2011) http://nuclearradiophobia.blogspot.com/p/radiation-iseverywhere-and-always-has.html

[11] Ramasamy, V. and Suresh, G. Meenakshisundaram, V., Characterization of Minerals and Naturally Occurring Radionuclide, Research Journal of Applied Sciences, Engineering and Technology.3 pp:140144,2009

[12] Taskin,H., Karavus, M.,Ay.P. Topuzogly, A. Hidirogly, S. and Karahan,G, Radiological Concentrations in Soil and Lifetime Cancer Risk due to Gamma Radioactivity in Kirklareli, Turke Journal of Environmental Radioactivity 100, pp:49-53,2009.

[13] Al-Ghamdi, H., Al-Muqrin, A., \& El-Sharkawy, A. (2016). Assessment of Natural Radioactivity and ${ }^{137} \mathrm{Cs}$ in some Coastal Areas of the Saudi Arabian Gulf. Marine pollution bulletin, 104(1-2). :29-33.

[14] Kernfors Chung Sanlage Julich, Technical reports series No.295, "M. of Radionuclides in food and the Environment", IAEA, 1989.

[15] Environmental Protection Department, Lead Pollution in Baghdad, Internal Report, Ministry of Health, Baghdad (1984-1985). 
[16] Miglierini M.," Detectors of Radiation", E. Wigner Publisher on Reactor Physics Experiments Journal, Vol.2, No.4, pp1-67,2004.

[17] Mehra, R., Singh, S., and Singh, K., "Analysis of Ra, Th and $\mathrm{K}$ in soil samples for the assessment of the average effective dose". Indian Journal of Physics, vol. 83,No. 7, p.1031-1037, (2009).

[18] Tawfiq, N. F., Mansour, H. L., and Karim, M. S.," Natural Radioactivity in Soil Samples For Selected Regions in Baghdad Governorate" ,International Journal of Recent Research and Review, Vol. VIII, Issue 1, p.1-7 March ,(2015).

[19] UNSCEAR 2008. United Nations Scientific Committee on the Effects of Atomic Radiation. Sources and effects of ionizing radiation. New York: The United Nations Scientific Committee on the Effects of Atomic Radiation.

[20] Khudair Sh. J., Ali A. M., Tawfiq N. F., (2020), Assessment of Natural and Industrial Radioactivity and Radiological Hazard in Sediments of Tigris River of Dhuluiya City, Iraq, Rafidain Journal Vol. 29, No. 4, ISSN:1608-9391, pp. 14-22, e-ISSN: 2664-2786

[21] Pourimani, R., Fardad R., and Khalili H., (2019)., Radiological Hazard Assessment of Radionuclides in Sediment and Water Samples of International Meighan Wetland in Arak, Iran. Iran J Med Phys 2020; 17:107-113.

[22] Abu-Taleb A., A Abbady and S.Harb. (2019). Assessment of Natural Radioactivity Level in Shore Sediment Sample From Nasser Lake at Aswan, Egypt. International Journal of Biomedical Engineering and Science (IJBES), 6(1).

[23] Kolo, M.T.; Baba-Kutigi, A.N.; Olarinoye, I.O.; Sharifat, I. (2012). Assessment of natural radioactivity levels and radiation hazards in the tertiary institutions in Minna, Niger State, Nigeria. Continental J. Environmental Sci., 6, 25-31. 